\title{
MAJOR CHEMICAL DISASTERS IN EGYPT AND ABROAD
}

PART 1:ABROAD

\author{
By \\ Emara,A.M and Zayet,H.H. \\ Department of Occupational and Environmental Medicine \\ Faculty of Medicine Cairo University
}

\begin{abstract}
:
Generally, the term disaster means sudden great misfortune and it is a destructive event that results in the need for a wide range of an emergency resources. Occurrence of disasters invariably has profound implication for public health. Disasters may be classified into natural, as floods and earthquakes, technological which are associated with industries and conflict-related disaster which are, usually, related to wars and revolutions.

In this article we are essentially concerned with chemical disasters, although other causes are important. We may discuss such causes in other articles.

The chemical disasters may occur suddenly or gradually according to their results or events.

There is a surprising fact that about $50 \%$ of acute disasters are due to unplanned transportation of chemicals.

The worst of acute chemical disasters happened in Bhopal, India (1984) where more than 2500 died and more than 250000 suffered due to the exposure of the people of Bhopal to the released methyl isocyanate pesticide. Another sudden episode occurred in Seveso, Italy (1976) where about 37000 persons were injured due to exposure to polychlorinated dibenzo-p-dioxin.

There were many gradual or insidious episodes, but we shall choose the most famous ones according to their place of occurrence, for example, Karkola, Finland (1930), Japan (two episodes,1939 and 1953) ,Turkey (1956), Iraq (1971), Love Canal, New York (1976) and Spain (1981). Other worldwide occurrence of medical problems for
\end{abstract}


example, acute air pollution episodes, polychlorinated biphenyls and their dangerous effects will be discussed.

Key words: disasters, air pollution episodes, polychlorinated biphenyls, itai itai and Minamata disease.

\section{Introduction:}

Nowadays there are increasing occurrences of chemical disasters, which are due to many factors; one of them is the presence and the dealing with innumerable chemicals.

Industrial chemical disasters do not only strike workers, but also the general population and the surrounding environment, i.e., soil, water, vegetations, seas and even buildings. The United Nation Environment Program (UNEP), in 1980, estimated that 60,000 chemicals are in use worldwide. Unfortunately, more than 600 new chemical substances enter the market each month. Such explosive growth in the rate of introduction of new chemical substances into the economy increases the likelihood that new agents will find their way into food and water supply unless health professionals maintain proper concern for environmental health (WHO/ EURO, 1987, and UNEP. 1999).

As an example of the huge production of organic chemicals in the United States since World War II, the annual production increased from 2 billion pounds to, about,
400 billion pounds nowadays. Therehas been an equally dramatic increase in the chemical production worldwide. Now many of these chemicals are present in the body tissues of the general population, as a consequence of environmental contamination from air, water, and solid waste pollution and, in the case of pesticides, as a result of deliberate environmental application. Due to this background contamination, numerous episodes of accidental adverse health effects have resulted, many of them are unfortunately not recorded (UNEP, 1999).

The subject of chemical disasters is very wide spread and dates back almost a thousand years ago, but the recorded number is not accurate, so we shall mention only the recorded major chemical disasters in the twentieth century.

The subject has been divided into two parts, the first part deals with the international disasters and the second part will be concerned with the Egyptian chemical disasters in the last fifty years. In this part we shall mention the factors affecting the occurrence and severity of chemical disasters, health and environmental effect, prevention and control. 


\section{Definition of disaster}

Disasters are catastrophic occurrences that invariably have profound implications for public health. The term "disaster" can be defined as, destructive event that results in the need for a wide range of emergency resources to assist and ensure the survival of the stricken population (Bertazzi, 1989).

\section{Generally disasters may be classified into:-}

1. Natural: which are precipitated by the forces of nature such as floods, earthquakes, fires, or hurricanes (Landesman, 2001).

2. Technological: refer to catastrophes associated with industrial processes or their by-products. These disasters involve explosions, fires, and chemical or radiological releases into the environment (Landesman, 2001).

3. Conflict - related disasters, or complex emergencies are the result of interrelated social, economic, and political problems and almost always involve armed confrontation. Since1980, there have been over 150 major armed conflicts and in 1995, there was an estimated 26 ongoing wars (Tapsell, 2000). In 2011, there were at least six Arabic revolutions and conflicts.
The importance of disasters has been recognized by the designation of the 1990 s as "The international decade for natural disaster reduction "by the United Nations.

There are two types of natural disasters: climatological (e.g. floods and storms) and geological (e.g. earthquakes and volcanoes)

In approximate order to the importance of their effects on humans, the most destructive natural disasters are climatological rather than geological disasters. In contrast, many disasters have large elements of human causation either accidental or intended (Murray and Good Fellow, 2002).

\section{Chemical disasters:}

Can be defined as environmental deterioration due to extensive contamination with chemicals. After the Second World War, there was rapid growth and expansion of the chemical industry. This has led to the occurrence of hundreds of chemical accidents. The major hazard incident data service (MHIDS), one of the most comprehensive data banks, contains over 3000 records concerning chemical accidents which have occurred in the last 25 years with an off-site impact in some 95 countries (Burkle, 1995) . 
Chemical disasters can be classified into four types:

(1) Sudden or acute disasters.

(2) Gradual or insidious disasters.

(3) Major air pollution disaster and.

(4) Wars and civil conflicts (should not be mentioned here).

1- Sudden or acute disasters: These are due to sudden, unexpected release of unusual quantities of toxic chemicals during a short period of time, resulting from fires, explosions, chemical reactions, and mechanical failure or otherwise, resulting in acute effects. The number of new cases decreases and they become less severe as time goes by, chronic and delayed effects may occur. This also includes accidental consumption of large doses of toxic chemicals in food or water. The most common chemicals, which caused such disasters, are chlorine, gasoline, ammonia, sulfuric and hydrochloric acids.

More than $50 \%$ of those events occurred during transportation. Acute chemical releases and major accidents happen every year all over the world; but chemical disasters, which cause death and injuries on a large scale, are fortunately not very common. The worst of this kind of disasters happened in Bhopal, India, in 1984, and caused the death of thousands (about 2500) and injured about 250,000 people. In the days after the incident, it was estimated that nearly 100,000 people sought medical care for health problems caused by the exposure to the released methyl isocyanate pesticide (Murray and Good Fellow., 2002. Other).Other details on the health and environmental impact of this accident will be mentioned later under the title of major air pollution.

Even sudden disasters that are considered natural are often caused by preceding human activities. For example, disastrous flooding may be the result of deforestation or of construction of dams, or climate change (Burkle, 1995).

\section{2- Gradual or insidious releases:} These are due to gradual release of a toxic substance that reaches man directly or indirectly. Accumulation leads to health effects that may be subacute or chronic. Cases increase in number and severity by time, unless there is intervention to stop the release. Deaths or delayed effects (genetic, carcinogenic, etc.) may be observed. An example of this type happened in Finland, in a village named "Karkola". In the population center, there was an industrial facility including a sawmill, located over an 
important ground water area. Since 1930, the mill used 7-10 tons of fungicides per year (tri-, tetra- and pentachlorophenol). In 1987, it was noted that the ground water and local water plant were contaminated with chlorophenol. The populations of the community were exposed to chlorophenol by drinking water and by eating fish that was caught from a nearby-contaminated lake. This was a probable cause of the higher incidence of non-Hodgkin lymphoma among men in "Karkola" (UNEP, 1999).

In Japan from 1939 _ 1954, a zinc lead cadmium mine discharged its waste water into a river, which was used for irrigation of rice fields and for drinking, over a period of 15 years. Approximately 200 persons developed a disease characterized by severe pain in the bones waddling gait, amino - aciduria, glycosuria, severe osteomalacia and multiple pathological fractures, a disease known as Itai-Itai. Minamata disease is also a famous example of this type. In 1953 unusual neurological disorders began to strike people living in fishing villages along Minamata Bay, Japan. The disease was named Kibyo, the "mystery illness". After numerous investigations, poisoned fish emerged as the probable culprit, and in 1957 the disease was produced experimentally by feeding cats with fish caught in the bay. The following year, the suggestion was put forward that the clinical picture of Kibyo, which included polyneuritis, cerebellar ataxia and cortical blindness, was similar to that due to poisoning by alkyl mercury compounds. A source of organic mercury had to be sought, and it was eventually found in a factory discharging its effluent into Minamata Bay. By July 1961, the disease had occurred in 88 persons, of whom 35 (40\%) had died (El Samra and El Batanounny., 1997).

In Turkey (1956) a similar episode happened due to the use of seed grain treated with hexachloro- benzene as a fungicide. A serious catastrophe had occurred due to ingestion of these seeds intended for planting. This resulted in more than 3000 cases of poisoning, 300 of them died from porphyria which was manifested as porphyria cutaneatarda characterized by severe skin manifestations as photosensitivity, bullae formation , deep scar, alopecia, and permanent loss of body hair and skin atrophy (Schmid, 1960).

In Iraq (1971) another fungicide, methyl mercury was used for treatment of seed grain. The farmers were aware that the grain had been treated by toxic fungicide but many of them washed off the red dye 
that marked the grain by water and used it as a food (latency of adverse effects of this fungicide is $2-3$ weeks ) The contaminated flood was eaten for about 2 months, then there was numbness, tremor, ataxia, up to complete paralysis, loss of vision, hearing and speech , coma , and death . About 6530 persons were hospitalized and 459 died. Blood levels were about 20 -25 microgram/ $\mathrm{dL}$ (normally less than 3 microgram/dL) of blood and urine should be less than 10 microgram/dL (Bakir et al., 1973).

Examples of insidious and continuing disasters include the leakage of toxic chemicals from dump site at Love Canal in New York. There were major environmental problems as a result of unplanned and unhealthy dealing with the hazardous wastes at love Canal area of Niagara Falls, New York. What happened in New York District in 1976 was an example of unplanned disposal of municipal rubbish which was thrown in a huge pit without any scientific rules. The story began more than 120 years ago, in1892; William T. Love set out to fulfill a dream of developing a new industrial complex in Niagara Falls using the water power derived from the Niagara River in production of electricity which is necessary in industries. As a part of the project, Love proposed the construction of Niagara canal (about $15 \mathrm{Km}$ ) between the upper and lower Niagara River. After digging the canal, the project was halted due to bad financial times. Some company purchased the canal and began using it as an industrial dump site. Thousands of tons and drums of toxic chemical waste and residue had been buried between 1950- 1960. In 1960 - 1970 hundreds of single family homes, schools and playing fields were established at the periphery of the canal. In 1976, after 6 years of unusually heavy rain and snow, chemicals began seeping in and outside the buildings adjacent to the canal. In 1978 the N. y. state termed the Love Canal area a grave and imminent peril to the health of those living nearby. There were abnormal numbers of miscarriages; birth defect, cancer and a variety of other illnesses .Families adjacent to the canal were evacuated.More than 80 different chemicals compounds were identified in the air, water, and soil around Love canal. More than 10 of these were known or suspected chemical mutagens or carcinogens, and many years will be needed to determine the true magnitude of adverse health effects (Department of Health of the State of New York, 1980).

Another example is the Toxic Oil Syndrome, which happened in Spain in 
1981, where 340 people died and over 20,000 persons were affected in a period of about 13 months. An epidemiological study revealed the association of this disease with the consumption of inexpensive denatured rape seed oil, sold in unlabeled plastic containers by street vendors (El Samra and El Batanouny., 1997).

Other famous toxic chemicals which are very dangerous to humans and the environment are polychlorinated biphenyls (PCBs), this is a large family of chlorinated aromatic hydrocarbons, and PCBs refers to 209 possible chlorobiphenyl isomers with differing numbers of chlorine molecules attached to the basic biphenyl structure.

Polychlorinated biphenyls are aromatic chemicals that do not occur naturally in the environment.

\section{Production levels and uses of PCBs, and health effect:}

The first chlorinated biphenyl was synthesized in 1864 , but it was not until 1929/1930 that the PCBs were produced commercially for use after the discovering its excellent properties:
(a) As dielectrics in transformers and large capacitors;

(b) In heat transfer and hydraulic systems; (c) In the formulation of lubricating, and cutting oils and wax extenders;

(D) As plasticizers in paints, and as ink solvent/carriers in carbonless copy paper, adhesives, sealants, flame retardants, and plastics (Fischbein et al., 1979).

Over one million tons of $\mathrm{PCBs}$ have been produced commercially under a number of trade names, such as Aroclor, Fenclor, Clophen, and Kanechlor.

Details of the production and uses of PCBs in the USA have been released, and have been summarized by Nisbet \& Sarofim (1972). Annual production increased steadily from 1930 and reached a maximum of 33000 tons in 1970 . After 1970, production decreased sharply owing to the voluntary limitation of sales by the Monsanto Company, the major manufacturer in the USA; between 1930 1975 approximately 1.4 billion pounds of PCBs were produced in the USA only. PCBs are readily absorbed through the respiratory tract, skin,G.I.T., metabolized in the liver and their distribution is primarily into fat. Many isomers are resistant to metabolism , this may be the cause of bioaccumulation of PCPs in fat even at low exposure, and the persistence of PCBs in fatty tissues 
years after exposure . In addition all PCBs are contaminated with small but highly toxic concentrations of polychlorinated dibenzofarans PCDs and polychlorinated terphenyls PCTs, (Ishi, 1972).

During the period 1980-84, the production in some European countries was as follows: France, 16200; Federal Republic of Germany, 24200; Italy, 4500; and Spain, 3400 tons. After 1984, production was continued only in France and Spain (WHO/ EURO, 1987).

By the end of 1980, the total amount of PCBs produced was I 054800 tons (of which approximately half was used in transformers and capacitors), divided between the following countries (in tons): USA, 647 700; Federal Republic of Germany, 130 800; France, 101 600; United Kingdom, 66 800; Japan, 59 300; Spain, 25 100; and Italy, 23500 (WHO/ EURO, 1987).

Van Derkolk (1984) found that fat levels of PCPs were 300-400 times higher than serum level. Generally serum levels in nonoccupationally exposed individuals are less than 10 parts per billion.

Tolerance levels of PCBs in food are based on the analysis that followed a contamination episode in Japan. In 1968, in the western part of Japan,chloracne was noted in a number of families. Chloracne is more severe and has different distribution form acne found in adolescents. Comedones - with or without cysts and pustules - are found typically on the malar surfaces, earlobes, post auricular, and suboccipital areas. Cysts containing straw - colored liquid are almost pathognomonic for chloracne. In more severe cases, it is found anywhere on the trunk and limbs, including the antecubital fossa. Follicular orifices are filled with sebaceous and keratinous material. Melanosis and a secondary inflammatory reaction may be present. Chloracne is extremely resistant to treatment, and the various medications used for acne have limited effectiveness. It probably results from interference with vitamin A metabolism in the skin with disturbances of the epithelial tissues of the pilosebaceous tract.

Further epidemiologic investigation revealed additional affected individuals consuming a particular brand of rice oil contaminated with PCBs. The PCBs were shown to have leaked into the rice oil from process equipment that used PCBs as a heat-transfer fluid. By the end of 1977, 1665 individuals met the diagnostic criteria for what is now called Yusho disease. 
The initial manifestations of the disease included not only chloracne, but also systematic complaints of loss of appetite, nausea, vomiting, weakness, and numbness of the extremities. Other physical findings included pigmentation of the face, palpebral conjunctiva, gingiva, and nails, and hypertrophy and increased secretion of the meibomian glands. Patients were followed from 1969 to 1975.

In addition to the acute symptoms of upper respiratory tract irritation. Chronic workplace exposure to PCBs also has resulted in chloracne. The relationship between dose of exposure and the appearance of chloracne was inconsistent, although chloracne persists for years after exposure has ceased (Chang et al, 1980 b).

PCBs have an efficient transplacental transfer, and adverse reproductive effects of $\mathrm{PCBs}$ have been reported in many animal species; these include failure of implantation, increased number of spontaneous abortion, and low birth weight of litters. In Yu-cheng (oil disease), mothers were exposed to PCBs and their heat-degradation products from the ingestion of contaminated rice oil in 1979. Children of these mothers were born growth retarded, with dysmorphic physical findings, delayed cognitive development, and increased activity levels. Rare cases of chloracne and, more commonly, nail abnormalities have been found in $\mathrm{Yu}$ cheng children. Prenatal exposure to PCBs predicts poorer cognitive abilities, impaired development, and endocrine abnormalities in the offspring of women with exposure to PCBs in the environment or from eating PCBs contaminated fish; these effects appear long-lasting in follow-up studies. Other abnormalities may be found e.g. increased chromosomal aberration among PCBs-exposed workers, hepatocellular carcinomas, increased risk of malignant melanoma and brain, liver, biliary, stomach and thyroid cancers. One recent study indicated that PCB-exposed persons had an excess of amyotrophic lateral sclerosis, Parkinson disease and dementia (Masuda and Yoshimura, 1984).

The following articles are examples of meticulous researches worldwide concerning the dangerous effects of POne hundred and thirty patients (46 males and 84 females) exposed accidentally to PCBs in Taiwan, were examined for ocular manifestation in 1979-80. Eye discharge was present in $80.5 \%$, swelling of the upper lids in $60.4 \%$, pigmentation of conjunctiva in $67.6 \%$, hypersecretion and cystic swelling of the meibomian glands in $70.7 \%$. Heavy 
pigmentation of the meibomian glands occurred in patients whose blood PCBs concentration was above $40 \mathrm{ug} / \mathrm{litre}$. There was a correlation between the ocular effects and the blood concentration of PCBs (Chen et al, 1980).

Wong et al. (1985), determined the enzyme activity in placental tissue, obtained from 4 women who were exposed to contaminated rice - oil in Yu-Cheng 3-4 years before conception. Placental homogenates showed increases in monooxygenase enzymes including aryl hydroxylase, 7-ethoxycoumarin O-deethylase, and diol, quinine and phenolic metabolites of benzo (a) pyrene .

Lu \& Wong (1984) described, in detail, the dermatological, medical, and laboratory findings on 829 patients (half males and half females) in Taiwan, poisoned with PCBs and related compounds. The ages of the patients ranged from 7 days to 78 years.

Chang et al., (1980a, b) found that the most common symptoms noticed were acneiform eruptions and follicular accentuation, skin and nail pigmentation, swelling of the eyelids and increased discharge from the eyes, headache, nausea, and numbness of the limbs. The major blood disorders were decreased erythrocyte counts, haemoglobin concentration, and gamma-immunoglobin, and increased white blood cell counts, serum triglyceride levels, and SGOT,SGPT, and serum alkaline phosphatase activities . Decreased concentrations of deltaaminolaevulinic acid and uroporphyin were also observed.

\section{Effects of PCBs on babies and infants:}

Wolff (1985) reported diminished growth in boys, but not in girls, who had consumed the contaminated oil. Babies born to Yusho mothers were smaller than normal. Newborn babies showed a dark brown skin pigmentation that disappeared after a few months, some had spotted and sporadic ossification of the skull and facial oedema with exophthalmia.

Generally the exposed children were shorter and lighter than the controls; they had more frequent abnormalities of the gingiva, skin, nails, teeth, and lungs than control children. The exposed children showed delay in development milestones, deficits on formal development testing, and abnormalities in behavioral assessment.

A follow-up study was carried out to determine the relationship between PCBs in mother's serum and breast milk and the health and development of the born infants, in Sheboygan, Wisconsin, USA, 
during the period 1980-81. Seventy-three mothers gave birth to 62 infants that were breast-fed and 11 that were bottle-fed. The age of the mothers ranged from 18 to 36 years. The mean serum PCB level from the study population was $5.76 \mathrm{ug} /$ litre (range, 1.29-14.9 ug/litre) breast milk contained a mean PCB level of $1.13 \mathrm{mg} / \mathrm{kg}$ (range 0.29 $4.02 \mathrm{mg} / \mathrm{kg}$ ) on a fat basis. The mother's blood serum PCB level during pregnancy was positively associated with the number and type of infectious illnesses the infants suffered later, such as colds, earache, and influenza during the first 4 months of life . The development and growth of the infant up to the age of 4 months was normal and was not affected by PCBs levels (Smith, 1984 and WHO/EURO 1985).

\section{3-Major Air Pollution Disasters} Worldwide: Several cities experienced acute air pollution disasters in this century. In general, when we refer to acute episodes of air pollution, we have in mind three classic incidents: the Meuse Valley in Belgium (1930), Donora, Pennsylvania (1948) and London fog (1952). In these incidents, there was temperature inversion for continuous three or four days during which time the concentration of pollutants (mainly smoke and sulfur dioxide) rose well above the normal levels for these heavily polluted areas (Bertazzi. 1989).
In 1930 in the Meuse Valley (Belgium), several people were hospitalized and died as the result of heavy air pollution. Meteorologically, there was anticyclonic weather characterized by high atmospheric pressures and mild winds with temperature inversion. The investigators ultimately concluded that sulfur oxides were the most likely culprits. Furthermore, synergistic factors such as the age and past history of lung and heart disease of patients as well as the presence of other pollutants played a great role. Control measures were finally directed at the major polluting sources.

Poza Rica Disaster (Mexico), 1952. This incident claimed 22 lives and hospitalized 320 people. Hydrogen sulfide pollution with anticyclonic weather and temperature inversion were responsible (Bertazzi, 1989).

Seveso explosion (Italy), 1976. An explosion at the Icmesa chemical plant released a cloud blanket of dioxin that resulted in social disruptions and as yet unspecified toxic effects in an almost science fiction scenario (Anonymous . 1983).

On December 3, 1984, the world's deadliest Industrial Disaster occurred in Bhopal, India, when methyl isocyanate 
(MIC) vapor was vented into the atmosphere as the sunray reaction in one of the tanks in which MIC was stored and malfunctioning safety systems within a Union Carbide plant in Bhopal. Weather conditions at the time of the chemical release resulted in an atmospheric inversion. This inversion caused the plume of MIC to move slowly across the ground, spreading throughout residential neighborhoods and public gathering places. Because the release occurred at night and because warnings of the release were either delayed or not issued, many victims became aware of the dangers only when they were awakened by the irritating effects of MIC to their eyes and throats. In the darkness, victims suffering from the effects of MIC were unable to determine the precise source of the toxic plume. Unfortunately, some moved toward the source of MIC rather than toward areas of relative safety. More than 2,500 people in the adjacent community died, and more than 250,000 persons were affected by the chemical release (Zaidi, 1986).

Thousands of victims were urgently in need for medical assistance from an overwhelmed local medical facility. At the time of the disaster, many community officials and residents had no knowledge about the types of hazardous materials produced and contained within the Union Carbide Plant. Consequently, emergencyresponse authorities were initially unclear about the nature and toxicity of the offending chemical agent, the type of medical treatment needed, and the extent of decontamination. Significant neurological, reproductive, neurobehavioral, and psychological effects were also observed (Bertazzi., 1989).

OtherformsofLong-termandcontinuing human-made disaster include global warming (the greenhouse effect) caused by heat trapping gases in the atmosphere (Carbon dioxide, methane, nitrous oxide, chlorofluorocarbons, water vapour), depletion of ozone layer due to the use of aerosolized chlorofluorohydrocarbons, and acid precipitation (UNEP. 1999).

\section{4 - War and Civil Conflict:}

As for the "causes" of wars, the most frequent objectives were territory and independence. However, civil wars representing power conflict within nations, have increased sharply in the twentieth century, and are now by far the major form of warfare.

\section{Chemical Weapons:}

Chlorine, phosgene, mustard gas and "tear gas" (Acrolein) were used extensively 
in World War I. Also, Germany with troops (this subject will be discussed with its excellent dye industry and facilities the major chemical disasters in Egypt for pesticide production developed the in part two). Acrolein lacrimating gas, cholinesterase inhibitors known as "nerve gases" during World War II.

The United States used tear gases and herbicides in the war in Vietnam, and there are detailed reports of the use by Korea and Israel of tear gases in large quantities in civil disturbance.

Mustard gas and possibly tear gas and other chemical weapons were used in the 1980s in the Iran-Iraq War.

In 2011 the Peaceful Revolution of Young Egyptians was aggressively attacked by Adly, Mubarak policemen which is an irritant highly soluble gas was previously used by American and Israel in Gulf and Gazza wars and was blamed to be genotoxic and carcinogenic. It causes severe lacrimation and irritation of exposed areas particularly the face (eyes and month), upper respiratory tract irritation with cough and sneezing, with probably genotoxic and carcinogenic hazards in the future.

The following tables (I\& II) show some details about major chemical disasters worldwide (I) and Arab \& African countries (II): 
Table (1)

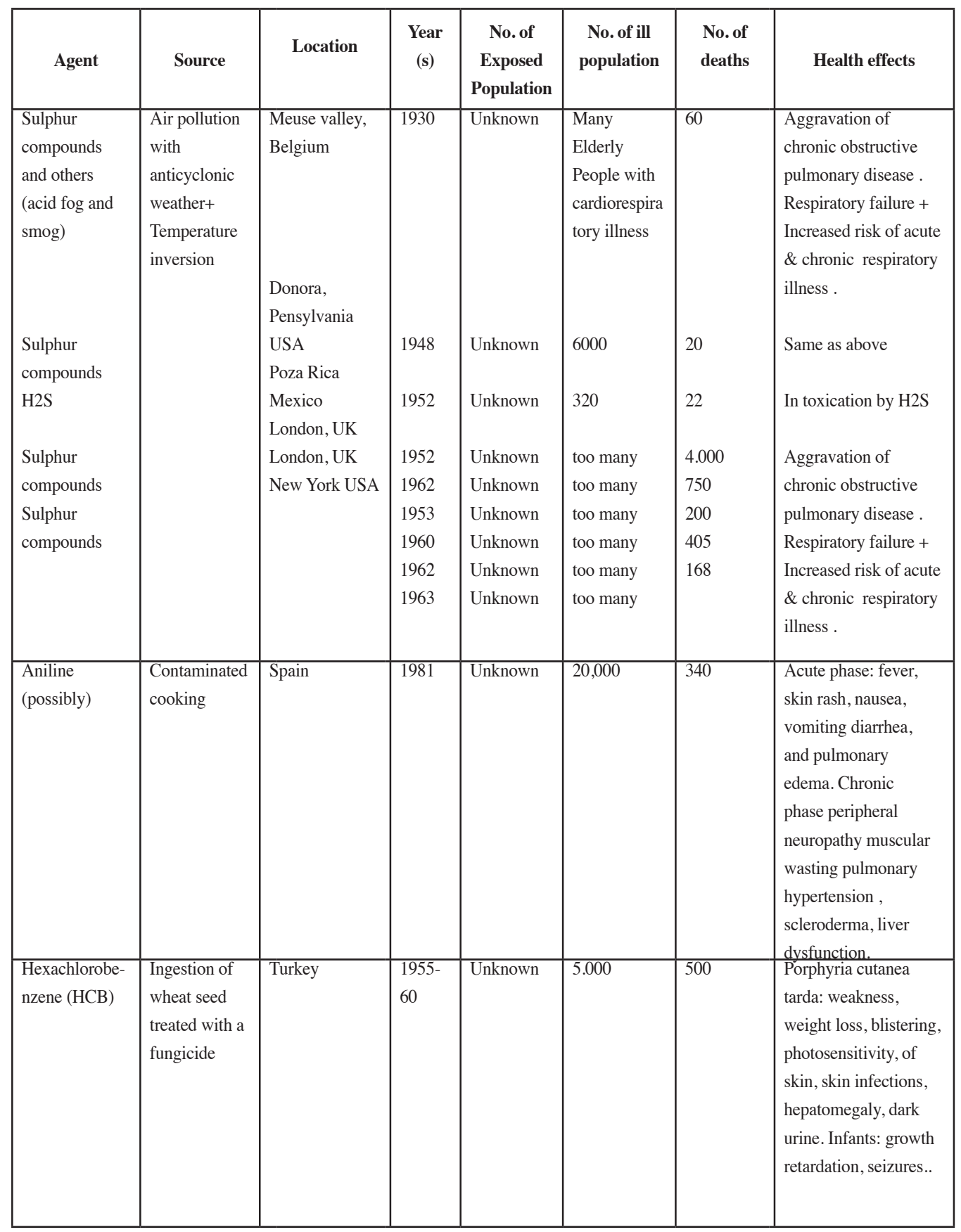




\begin{tabular}{|c|c|c|c|c|c|c|c|}
\hline Agent & Source & Location & $\begin{array}{l}\text { Year } \\
\text { (s) }\end{array}$ & $\begin{array}{l}\text { No. of } \\
\text { Exposed } \\
\text { Population }\end{array}$ & $\begin{array}{l}\text { No. of ill } \\
\text { population }\end{array}$ & $\begin{array}{l}\text { No. of } \\
\text { deaths }\end{array}$ & Health effects \\
\hline $\begin{array}{l}\text { Polychlorinat- } \\
\text { ed biphenyls }\end{array}$ & $\begin{array}{l}\text { Contaminated } \\
\text { rice oil }\end{array}$ & Japan & $\begin{array}{l}1968- \\
73\end{array}$ & Unknown & 1.200 & 22 & $\begin{array}{l}\text { Yusho Disease, hyper } \\
\text { secretion of eyes, } \\
\text { acneform, eruptions, } \\
\text { skin hyperkeratosis } \\
\text { and dark pigmentation } \\
\text { of skin, nails \& } \\
\text { mucous membranes, } \\
\text { severe headache, } \\
\text { nausea, numbness of } \\
\text { extremities. }\end{array}$ \\
\hline Methyl Mecury & $\begin{array}{l}\text { Ingestion of seed } \\
\text { grain treated } \\
\text { with } \\
\text { mercurial } \\
\text { fungicide } \\
\text { Discharge of } \\
\text { mercury from } \\
\text { industry in } \\
\text { Minamata Bay } \\
\text { resulting in } \\
\text { biomagnification } \\
\text { in fish leading } \\
\text { to human } \\
\text { poisoning } \\
\text { (Minamata } \\
\text { disease) }\end{array}$ & $\begin{array}{l}\text { Iraq } \\
\text { Minamata } \\
\text { Bay, Japan }\end{array}$ & $\begin{array}{l}1959- \\
60 \\
\\
1953- \\
61\end{array}$ & $\begin{array}{l}\text { Unknown } \\
\text { Unknown }\end{array}$ & $\begin{array}{l}7.000 \\
\\
111 \text { with } \\
\text { neurological } \\
\text { diseases, } \\
40 \text { with } \\
\text { congenital } \\
\text { malofrmat- } \\
\text { ions }\end{array}$ & $\begin{array}{l}500 \\
\\
41\end{array}$ & $\begin{array}{l}\text { Sever malaise, } \\
\text { paresnthesia of } \\
\text { extremities, slurred } \\
\text { speech, ataxia } \\
\text { Constricted visual field, } \\
\text { severe brain damage in } \\
\text { infants of exposed } \\
\text { Mothers, chorea, loss } \\
\text { of vision, hearing and } \\
\text { speech. }\end{array}$ \\
\hline Cadmium & $\begin{array}{l}\text { rice and water } \\
\text { Contaminated } \\
\text { with cadmium } \\
\text { from a near mine } \\
\text { discharging } \\
\text { waste water into } \\
\text { a local river from } \\
\text { which people } \\
\text { drink and irrigate } \\
\text { rice }\end{array}$ & (1) & $\begin{array}{l}1939- \\
54\end{array}$ & Unknown & 200 & & $\begin{array}{l}\text { Itai- Itai «ouch ouch» } \\
\text { disease severe pain in } \\
\text { bones, waddling gait, } \\
\text { aminoaciduria, } \\
\text { glycosuria severe, } \\
\text { osteoporosis with } \\
\text { multiple fractures }\end{array}$ \\
\hline
\end{tabular}




\begin{tabular}{|c|c|c|c|c|c|c|c|}
\hline Chlorine & $\begin{array}{l}\text { Cargo train } \\
\text { accident with } \\
\text { tanks containing } \\
\text { liquefied } \\
\text { chlorine }\end{array}$ & $\begin{array}{l}\text { Missouga, } \\
\text { Canada }\end{array}$ & 1979 & 250,000 & Evacuated & Evacuated & $\begin{array}{l}\text { Potentieal health effects: } \\
\text { Acute respiratory distress } \\
\text { with cough, } \\
\text { dyspnea, chest pain, } \\
\text { Hemoptysis. Acute } \\
\text { pulmonary edema and } \\
\text { Chronic } \\
\text { pneumonitis. }\end{array}$ \\
\hline Agent & Source & Location & $\begin{array}{l}\text { Year } \\
\text { (s) }\end{array}$ & $\begin{array}{l}\text { No. of } \\
\text { Exposed } \\
\text { Population }\end{array}$ & $\begin{array}{l}\text { No. of ill } \\
\text { population }\end{array}$ & $\begin{array}{l}\text { No. of } \\
\text { deaths }\end{array}$ & Health effects \\
\hline Dioxin & $\begin{array}{l}\text { Release of } \\
\text { polychloronated } \\
\text { dibenzo-p- } \\
\text { dioxns } \\
\text { (PCDDs) from } \\
\text { an } \\
\text { industrial plant }\end{array}$ & $\begin{array}{l}\text { Seveso, } \\
\text { Italy }\end{array}$ & 1976 & 27,000 & Evacuated & Evacuated & $\begin{array}{l}\text { Potential health effects : } \\
\text { Chloracne, } \\
\text { polyneuropathy, optic } \\
\text { neuropathy } \\
\text { with diminution of } \\
\text { Vision, nystagmus. } \\
\text { Hepatomegaly with } \\
\text { elevated serum. enzvmes }\end{array}$ \\
\hline $\begin{array}{l}\text { Methyl } \\
\text { Isocyanate }\end{array}$ & $\begin{array}{l}\text { Release of large } \\
\text { amounts of } \\
\text { methylisocyanate } \\
\text { from pesticide } \\
\text { factory due to } \\
\text { explosion of } \\
\text { storage tank. }\end{array}$ & $\begin{array}{l}\text { Bhopal, } \\
\text { India }\end{array}$ & 1984 & $\begin{array}{l}\text { Population } \\
\text { at Bhopal }\end{array}$ & 250,000 & 2,500 & $\begin{array}{l}\text { Immediate: skin and } \\
\text { respiratory irritation, } \\
\text { wheezing, chest, } \\
\text { tightness, cough, } \\
\text { suffocation and } \\
\text { pulmonary edema. } \\
\text { Later: COPD } \\
\text { and bronchial hyper- } \\
\text { reactivity. }\end{array}$ \\
\hline
\end{tabular}


Table (II) Recorded major chemical Disasters in Arab \& African countries ( UNEP, APELL , 1999)

\begin{tabular}{|c|c|c|c|c|}
\hline \multirow{2}{*}{ Year } & \multirow{2}{*}{ Location } & \multirow{2}{*}{ Products involved } & \multicolumn{2}{|c|}{ Number of } \\
\hline & & & Deaths & Injured \\
\hline 1978 & Tunisia, Mancuba & Ammonium nitrate & 3 & 150 \\
\hline 1980 & South Africa & Crude oil & 36 & - \\
\hline 1990 & Lebanon, Chtaura & Fuel Oil & - & 45 \\
\hline 1990 & Saudi Arabia, Rastan & Kerosene and benzene & 1 & 2 \\
\hline 1991 & Ethiopia, Addis Ababa & Ammunition & 100 & 200 \\
\hline 1992 & Senegal, Dakar & Ammonia & $>40$ & $>300$ \\
\hline 1992 & Lebanon & Explosives & 30 & . \\
\hline 1992 & Libya, Al-Sanouani & Fireworks & 17 & 143 \\
\hline 1994 & Nigeria, Onitsha & Fuel oil & 60 & - \\
\hline 1995 & Jamaica & Chemicals & - & - \\
\hline 1996 & Yemen, Aden & Ammunition & 38 & $>100$ \\
\hline
\end{tabular}

* Awareness and Preparedness for Emergencies at Local Level (APELL ,1999)

N.B. As regards the impact, prevention and control of chemical disasters will be discussed in part II 


\section{References:}

1. Anonymous (1982): toxic oil syndrome, lancet 1,1287-8 .

2. Bakir, F., Damluji, S.F., and Amiz,L. (1973): Methyl mercury poisoning in Iraq. Science, 181,230 .

3. Bertazzi.PA. (1989):Industrial disasters and epidemiology. Scand.j. work.Env.\& health 15:85100.

4. Burkle FM (1995): Complex, humanitarian emergencies: Concepts and participants. Pre hospital and disaster medicine 10 (1), 36-42.

5. Chen, P.H., Graw,J.M., Wong, C.K. and Chen,C.J.(1980):Clinical and metabolic abnormalities associated with accidental exposure to PCBs in Taiwan. Bull environs. Centam. Toxicol. 25,325-9.

6. CHANG, K-T. CHANG, J-S. HUANG, P-C. TUNG, T-C. (1980a): Study of patients with PCB poisoning. J. Formosan Med. Assoc79:304-13.

7. CHANG K-J, LU, F-J, TUNG, T-C, and LEE, T-P. (1980b) studies on patients with PCB poisoning. Determination of urinary coproporphyrin, uroporphyrin, delta-aminolaevulinic acid and porphobilinogen. Res. Commun. Chem. Pathol. Pharmacol, 30(3): 547-54.

8. Department of Health of State of New York (1980: Love Canal, Public Health, special report to the Governor and Legislature.

9. El Samra G.H., El Batanouny M.M. (1997): Environmental chemical disasters. In: Shahi GS, Levy B and Lawrence R (Editors) Environment, Development, and health toward a sustainable world. Springer publishing company, United States of America. P: 325-37.
10. Fishbein, A.,Wolff, M.S and Lili S.R. (1979): Clinical findings among PCBs exposed workers. Ann. N.Y.Acad. Sci., P320.

11. Ishi, H. (1972) PCB pollution in Japan, Tokyo, Japanese Public Health Association, (Environ. H. report No. 14 pp. 13-28.

12. Landesman, L (2001): Public Health Management of disasters: The practice guide, American Public Health Association, Washington, D.C.

13. 13- LU, Y-C \& WONG P-N (1984): Dermatological, medical and laboratory findings of patients in Taiwan and their treatments. Am. J. Ind. Med, 5:81-115.

14. Masuda, Y. and Moshimara, H. (1984): Polychlorinated biphenyls and dibenzofurans in patients with Yosho and their toxicological significance: a review. Am.J.Ind. Med.5:31-44.

15. Murray V, Goodfellow F (2002): Mass casualty chemical incidents towards guidance for public health management. Public Health, 116(1):2-14. Jan.

16. Nisbit, I.C.T. and Sarofim, A.F. (1972): Rates and routes of transport of PCBs in the environment. Environ. Health perspect, 1:21-38.

17. OECD (1982): Report on the implementation by member countries of the decision by the council on the protection of the environment by control of polychlorinated biphenyls, Paris, Organization of economic co-operation and development (ENV/CHEM/812).

18. Schmid,R., (1960): Cutaneous porphyria in Turkey. N.Eng. J. Med, 263- 67.

19. SMITH, B.J. (1984): PCB levels in human fluids: Sheboygan case study, Madison, Wisconsin, University of Wisconsin, Sea grant Institute (Technical report No. WIS-SG-83-240).

20. Tapsell SM (2000): Follow-up study of the health effects of the Easter 1998 flooding in 
Banbury and Kadlington. Report to the Environment Agency. Enfield: Flood Hazard Research centre.

21. UNEP (1999): Disasters by location: Awareness and Preparedness for emergencies on a local level.

22. US EPA (1985): Polychlorinated biphenyls in electrical transformers, final rule (part IV). Fed. Reg, 50(137): 29170-29201.

23. Van Der Kolk, J. (1984): Consideration of a Codex approach to contamination of foodstuffs with PCBs. Joint FAW/WHO Food standards programme Codex Committee on pesticide residues, Sixteenth session, The Hague, 28 May-4 June 1984, Codex Alimentarius Commission (CX/PR84/10).

24. WHO/EURO (1985) :Organohalogen compounds in human milk and related hazards. Report on a WHO consultation, Bilthoven, 9-11
January 1985, Copenhagen, World Health Organization, Regional office for Europe (IPC/ CEH 501/m05).

25. WHO/EURO (1987): PCBs, PCDDs, and PCDFs: Preventation and control of accidental and environmental exposures, Copenhagen, world health organization, Regional office for Europe (Environmental health series 23).

26. Wolff, M.S. (1985): Occupational exposure to polychlorinated biphenyls (PCBs). Environmental health perspect. 60:133-8.

27. Wong, T.K., Everson, R.B. and HSU-TAO (1985) : Potent induction of human placenta mono-oxygenase activity by previous dietary exposure to polychlorinated biphenyls and their thermal degeneration products. Lancet march30:721-4.

28. Zaidi, S.H., (1986) : Bhobal and after. Am.j.ind. med., 9,215-16. 